\title{
IS MULTIPLE BORROWING A BAD SIGN? EVIDENCE FROM MICROFINANCE INSTITUTIONS IN PAKISTAN
}

\author{
Zahid Iqbal $^{1 *}$, Muhammad Akram², Hassan Ahmad ${ }^{3}$
}

${ }^{1 *}$ Ph.D., Scholar, Hailey College of Commerce, University of the Punjab, Lahore, Pakistan; ${ }^{2}$ Associate Professor, Hailey College of Banking \& Finance (HCBF), University of the Punjab, Lahore, Pakistan; ${ }^{3}$ Dongbei University of Finance \& Economics, China.

Email: ${ }^{1 *}$ zahidiqballak@ gmail.com, ${ }^{2}$ makram.hcc.pu.edu.pk@gmail.com, ${ }^{3}$ hassaan1214@hotmail.com

\author{
Article History: Received on $17^{\text {th }}$ May 2021, Revised on $27^{\text {th }}$ May 2021, Published on $6^{\text {th }}$ June 2021
}

\begin{abstract}
Purpose: To improve the loan repayment performance of Microfinance Institutions (MFIs) in Pakistan, this research not only analyses the direct effect of multiple borrowing on loan repayment performance but also determining the indirect impact of multiple borrowing on loan repayment performance through the mediating role of over-indebtedness and moderate role of moral hazard between over-indebtedness and loan repayment performance.
\end{abstract}

Design/methodology/approach: This study is based on a rich dataset comprised of information provided by the employees of MFIs working in Pakistan. The primary data were collected through the structural questionnaire, reliability and validity of construct were established in the light of different techniques including (1) Factor Loading (2) Cronbach's Alpha (3) Composite Reliability (4) Average Variance Extracted (5) Variance Inflation Factor (6) FornellLarcker Criterion and (7) HTMT Ratio. Moreover, structural equation modeling techniques were applied in this study and, hypotheses were tested through bootstrapping by using PLS-SEM.

Findings: The results confirm not the only direct impact of multiple borrowing on loan repayment performance and over-indebtedness but also mediating role of over-indebtedness between multiple borrowing and loan repayment performances. Aside from the direct influence of over-indebtedness on loan repayment performance, the moderate role of moral hazard on the association between over-indebtedness and loan payback was also found.

Application of the Study: The findings of this study will be communicated with all Microfinance Institutions (MFIs) in the future so that policies may be developed to address the factors that negatively affect the loan repayment performance of Microfinance Institutions (MFIs). Besides this, the outcomes of this study will also enable the MFIs to launch different loaning products that not only fulfill the borrower's requirements but also ensure the interest of MFIs.

Originality/value: Until now, the impact of multiple borrowing on loan repayment performance through mediating role of over-indebtedness and moderating role of moral hazard in the context of Microfinance Institutions (MFIs) of Pakistan have hardly been investigated. This study also enhances the understanding of MFIs regarding multiple borrowing and its subsequent impact on loan repayment performance. Moreover, the findings of this study enable the MFIs of Pakistan to improve their loan repayment performance by formulating the new lending policies in light of the finding of this study with special reference to multiple borrowing.

Keywords: Multiple Borrowing, Over-Indebtedness, Moral Hazard, Loan Repayment Performance.

\section{INTRODUCTION}

At least two decades ago in Pakistan, it is not feasible for poor people to obtain bank credit facilities without assets or collateral and poor people have to contact traditional money lenders for seeking credit facilities. However, after the emergence of Microfinance Institutions (MFIs), poor people were enabled to obtain credit facilities in form of small loans from MFIs without any collateral or securities. Indeed, Microfinance Institutions (MFIs) proved themselves one of the most important armaments against rapidly growing poverty in Pakistan. Microfinance is the most prominent program that provided small-scale loans to destitute people who were excluded from the financial market and unbanked in the eyes of conventional banking sectors. After that a swift competition was started in Pakistan among the MFIs due to this, the issue of loan repayment performance gets the attention of different financial regulators and researchers as well (Sawada, Tanaka, \& Mahmud, 2018).

Loan Repayment Performance is an important issue for the banking sector especially for Microfinance Institutions (MFIs) as the survival, growth, and stability of MFIs depends upon the loan repayment performance. As per the State Bank of Pakistan report, Non-Performing Loans increasing over the last five years rapidly, especially in Microfinance Institutions (MFIs) sector. Therefore, the issue of loan repayment performance required great attention from researchers. The relationship between the Microfinance Institutions (MFIs) and their client/customer depends upon the high repayment rate, hence Bond and Rai (2009) argue that if a customer intends to get the subsequent loan of a higher amount than the existing loan, then he/she has to pay his/her existing loan as per contractual agreement by following the all terms and condition with true letter and spirit. If a customer of MFIs fails to follows the terms and conditional of the loan agreement, then the performance of MFIs and clients will be affected adversely. Moreover, the client will not be able to obtain a subsequent loan of a higher amount than the existing amount of loan and MFIs will also lose its client. The better repayment rate of a client not only reduces MFI's dependence on subsidies but also ensures the survival, 
growth, and stability of banks. Besides this high repayment rate also ensured the provision of additional services for the client (Godquin, 2004).

As per the State Bank of Pakistan for since last five years Non-Performing Loans of Microfinance Banks increase from Rs. 894.82 Million to Rs. 13159.87 Million. The ratio of Non-Performing loans to gross advances increased from $1.62 \%$ to $6.13 \%$ in the last five years. Provision against Non-Performing loans to gross advances increased from $1.18 \%$ to $5.42 \%$ in the last five years. NPL ratio to shareholder equity also increases from $3.75 \%$ to $26.38 \%$ whereas a ratio of NPL write-off to NPL Provision enhanced from $117.11 \%$ to $146.58 \%$. Besides all this in the last five years' ratio of Provision against NPL to NPL increased from $72.91 \%$ to $88.48 \%$ (State Bank of Pakistan).

One of the major reasons for this loan repayment problem is the swift competition between MFIs enabled microfinance clients to take loaning facilities from more than one MFIs at the same time. The findings of various studies conducted on multiple borrowing and its impact on loan repayment performance indicated that taking loans by MFIs clients from more than one MFIs at the same time is creating serious loan repayment problems. Besides this literature showed that multiple borrowing enhances over-indebtedness and ultimately raised loan repayment problems especially in the context of the lower-income client (Vogelgesang, 2003). As a result, repeated borrowing can occasionally make clients poorer while also jeopardizing MFIs' long-term viability. (Vogelgesang,2003; Debnath \& Roy, 2018). Competition in MFIs have different pros and cons and one the of the major issues that arise due to competition in MFIs is the irresponsible lending, meaning that MFIs employees sanction loan to those borrowers, which do not fulfill the basic requirement of risk-related factors. Besides this MFIs employees do not care about the rules and regulations of MFIs and only considering the specific target that is allocated to them about gaining a new client. In case of strong competition, employees of one MIFs try to poach the client of other MFIs even at the cost of loan delinquency and loan default (Matzanke, 2014).

MFIs borrowers do multiple borrowing due to swift competition between various MFIs as each lending agency intends to poach the client their competitors even by violating the rules and regulations of his/her MFIs. Therefore, this type of aggressive lending leads to over-indebtedness, and these clients have to face severe loan repayment problems. (Matzanke, 2014) As concluded by Chen, Chang, and Bruton (2017) one of the key reasons for multiple borrowing and over-indebtedness is the market competition, and every lending agency intends to compete with other lending agencies at any cost. Swift competition amongst MFIs created serious loan repayment performance through multiple borrowing. He further added that clients usually did not leave the existing lender but also finding a new lender for taking an additional loan which damaged their repayment performance in the context of the existing lender. Besides this, he also considered that multiple borrowing is the consequence of informational asymmetry between the borrowers and lenders (Matzanke, 2014). Moreover, due to swift competition in MFIs, borrowers in Bangladesh have membership of various MFIs that leads to multiple borrowing. They mentioned that members of various MFIs lead to multiple borrowing that ultimately adversely affect the repayment performance of clients (Chaudhury \& Matin, 2002).

As per the findings of various academics and practitioners vicious circle of loan, recycling starts from multiple borrowing results in over-indebtedness and loan repayment problems through the moderating role of moral hazard (Pytkowska \& Spannuth, 2012; Matzanke, 2014). Multiple borrowing, also known as double-dibbing, client overlap, multiple borrowing, or cross borrowing, is the process of receiving a loan from multiple MFIs. (Diaz-Serrano \& Sackey, 2018). According to Schicks (2013), over-indebted customers consistently struggling to meet repayment deadlines and surrendered his/her resources to fulfill the contractual obligation of a loan agreement. This definition is more clientoriented and it indicates that over-indebtedness can arise even payment of a loan made in time but at the cost of various sacrifices including reducing food quantity, reducing the living standard, basic needs, and even personal resources. In short, if a borrower fails to pay his/her loan obligation as per contractual agreement or fulfill its loan obligation at the cost of sacrifices of various resources (Matzanke, 2014).

Whereas there is a common perception that a large number of MFIs borrowers creating agency problems through diversion from loan purpose and only a few borrowers used loan amount for investment purpose or invest loan amount in income-generating activities. However, a large number of MFIs borrowers create moral hazard issue by using loan amount for self-consumption such as in paying medical bills, educational fees, marriages of family members renovating the house, construction of houses, payment of existing loans, funeral, purchase of jewelry, mobile phone, motorcycle, and cultural events. Multiple borrowers soon face the problems of over-indebtedness that resulting loan delinquency and loan default issues. Moreover, loan repayment performance is referred to if any borrower fails to fulfill its contractual obligation as per the loan contractual agreement (Debnath \& Roy, 2018).

The findings of various studies that are conducted on multiple borrowing and its impact on loan repayment performance through the mediating role of over-indebtedness indicated contradicting results. Some studies indicated a positive impact of multiple borrowing on loan repayment performance and some studies showed that multiple borrowing created overindebtedness that adversely affect the loan repayment performance. Therefore, this research work will observe the incidence of multiple borrowing on loan repayment performance through the mediating role of over-indebtedness and moderating impact of moral hazard on the relationship of multiple borrowing and over-indebtedness (Debnath \& Roy, $\underline{2018)}$. 
The first major contribution of this study is that this study relates multiple borrowing with over-indebtedness. Secondly, this study creates a relationship between over-indebtedness and loan repayment performance, and finally, this study highlights the moderating impact of moral hazard between over-indebtedness and loan repayment performance. It is not necessary that only multiple borrowing create loan repayment problems directly but over-indebtedness creates mediating role to boost the loan repayment problems concerning multiple borrowing. Multiple borrowing adversely affects the loan repayment problems directly and through over-indebtedness, if borrowers spent to take a diversion from loan purpose by spending loan amount to fulfill his/her immediate needs instead of investing loan amount in productive manners (Green \& Liu, 2021).

Hence, we can address the five key questions: (1) Does multiple borrowing has a direct impact on loan repayment performance? (2) Secondly, does borrower who borrows money from more than one MFIs concurrently enhance their risk level in the context of over-indebtedness? (3) Third, does over-indebtedness client-facing repayment problems? (4) Fourth, does over-indebtedness influences the relationship of multiple borrowing and loan repayment problems? (5) Fifth, does moral hazard have moderating impact on the relationship between over-indebtedness and loan repayment performance?

The rest of the paper proceeds as follows: Section 2: comprises ifferent theories used in the support of this study, literature review, and hypothesis. Section 3 reveals the methodology used in this study. Section 4 will show the results of the study in the light of literature and theory and section 5 will be comprised of discussion, conclusion, limitation and implication, and future direction of research.

\section{LITERATURE REVIEW \& HYPOTHESIS}

As mentioned in the introduction section that this study is based on various theories. Therefore, details of theories that are used in the support of this study and relevant literature related to concerned variables are given as under.

\section{Theoretical Background}

The first theory that is used in this study is the Agency Theory. Agency theory stated that both Principal (MFIs) and Agent (Borrowers/Client) have unaligned goals due to this both principal and agent not followed the contractual obligation with true letter and spirit. As both parties in the contract principal and agent are not on the same page and working for their interest due to this loan repayment performance suffer adversely (Orichom \& Omeke, 2021). The second theory used in this study is the Asymmetric Information Theory. Asymmetric-Information situation raised if both borrower and lender were not on the same page in the context of information availability. In this situation borrower was unaware of the lender terms and condition of the loan and the lender was unaware of the borrower's financial conditions and business performance. As per this theory, both borrowers and lenders are not on the same page in the context of the availability of information that creating loan repayment performance issues (Muindi \& Mutwiri, 2021).

Moral Hazard Theory is the third theory used in this study. Moral Hazard Theory holds the client responsible for NonPerforming Loans. This theory postulated that clients taking loans from the business point of view but used loan amounts to fulfill their family's immediate needs and ultimately default. This theory is correlated with Client-Specific Factors (Sangwan, Nayak, \& Samanta, 2020). The fourth theory applied in this study is the Loan-Utilization-theory. The theory proved that severe monitoring of client enforced him/her to used loan amount on income-generating activities instead of on social disbursement. This theory holds responsible MFIs employees for poor loan repayment performance and is associated with MFIs Related Factors (Parvin, Birner, \& Mila, 2020).

\section{Impact of Multiple borrowing on Loan repayment performance}

There is no universal definition of multiple borrowing exist but based on the various previous research questions, research objectives, and available data it can be concluded that if a borrower involved or work with several MFIs to reduce his/her loan repayment problems is referred to as multiple borrowing (Puliyakot, 2020). The major reason for loan repayment problems in the context of multiple borrowing, poor business performance, and others family immediate needs. The author concludes that $34 \%$ of client-facing loan repayment problems due to multiple borrowing, $42 \%$ unable to fulfill his/her contractual obligation due to poor business performance, whereas $24 \%$ of clients faced severe loan repayment problems due to a family obligation. It means that majority of MFIs client fails to fulfill its contractual obligation as per loan contract agreement due to multiple borrowing and family obligation (Mwashiuya \& Mbamba, 2020).

According to Dhungana, Chapagain, and Ranabhat (2020), a large number of client who was engaged in multiple borrowing fails to repayment his/her outstanding loan. For instance, Mpogole, Mwaungulu, Mlasu, and Lubawa (2012) reported that in Bangladesh those clients involved in multiple borrowing facing serious loan repayment problems and their loan repayment rate declined. Chaudhury and Matin (2002) found that those borrowers who were involved in multiple borrowing their loan repayment performance were meager than their peers. They further added that those multiple borrowers who were very poor their loan repayment performance more worsen than the moderately poor multiple borrowers. Dattasharma, Kamath, and Ramanathan (2016) mentioned that those clients who are involved in multiple borrowing have to face more transaction costs since attending the weekly MFIs meetings has a higher opportunity cost in terms of wasting time. He also added that 19 households out of 20 were multiple borrowers facing 
serious repayment problems and almost their expenditure on food consumption also equal to their loan repayment amount.

$\mathbf{H}_{1}$ : Multiple Borrowing has a direct impact on Loan Repayment Performance in the context of MFIs Client in Pakistan.

\section{Impact of Multiple borrowing on over-indebtedness}

Only $5 \%$ of respondents believe that additional funds can be obtained through multiple borrowing and effectively used in the betterment of business and education of family members. Whereas $75 \%$ of respondents admitted that multiple borrowing created mental burden especially if the borrower involved in moral hazard and unable to fulfill his/her basic needs due to shortage of income. More than $80 \%$ respondent not recommended multiple borrowing as multiple borrowing have heavily disadvantages. However, the remaining $20 \%$ of respondents believe that multiple borrowing helpful if the money obtains through multiple borrowing was invested productively (Chichaibelu \& Waibel, 2017). Schicks define an over-indebted borrower /client as "who is consistently struggling to meet repayment deadlines and structurally has to make unduly high sacrifices related to his/her loan obligations" (Shreya, 2021).

As concluded by Schicks (2014) that multiple borrowing and over-indebtedness are closely associated with each other's, whereas due to over-indebtedness client business performance suffers, and the major portion of client income is used in debt servicing due to this client unable to pay his outstanding loans. They further added that as per their findings percentage of insolvency amongst single loan holders is only 5\% whereas the ratio of insolvency among multiple borrowers was $12 \%$. Besides this ratio of over-indebtedness among multiple borrowers is $11 \%$ and the ratio of overindebtedness among single loan holders is only $2 \%$. They further added that multiple borrower's business performances in terms of profit and growth were also lower than their peers. In Bosnia and Herzegovina, Maurer and Pytkowska (2011) found that Multiple borrowing and over-indebtedness are closely correlated with each other. Whereas those clients who were over-indebted and also fail to run their business efficiently facing serious repayment problems than those who perform well in business.

$\mathbf{H}_{2}$ : Multiple Borrowing has a direct impact on Over-Indebtedness in the context of MFIs Clients in Pakistan.

\section{Impact of over-indebtedness on loan repayment performance}

As per previous studies issue of over-indebtedness arises if borrowers sign various loan contractual agreements with more than one MFIs or NGO and consequently faces loan repayment problems. (1) In the Bangladesh context, Lamichhane (2021) briefed that borrowers who were involved in multiple borrowing their performance were better than their peers in the context of net wealth and enhancement of assets. However, they also agreed that the indebtedness level of multiple borrowers as high as compare to their peers, and the performance of multiple borrowers in terms of loan repayment was lower as compared to their peers. Burki (2009) did a study on multiple loans in Pakistan and discovered that accumulating a significant amount of debt linked with cross lending leads to over-indebtedness and repayment issues when the loan is not used for revenue-generating operations. He also mentioned that due to over-indebtedness client business performance suffers that ultimately create loan repayment problems for borrowers.

According to Faruqee et al. (2011) to enhancement in indebtedness results from multiple borrowing that leads to repayment problems especially in the context of moral hazard and poor client business performance. In the case of critical indebtedness, every minor movement in income and expenditure leads to financial disturbance. In these circumstances, multiple borrowers will be able to fulfill his/her loan obligation if he/she will be able to generate sufficient income through their business performance. Hossain et al. (2020) argue that the majority of borrowers who engaged in multiple borrowing failed to generate sufficient income from their investment to cover the interest charges of two or three loans and ultimately failed to fulfill his/her loan obligation as per contractual agreement.

$\mathbf{H}_{3}$ : Over-Indebtedness has a direct impact on Loan Repayment Performance in the context of MFIs Client in Pakistan.

\section{The mediating role of over-indebtedness on the between Multiple borrowing and loan repayment performances}

Multiple borrowing leads to over-indebtedness and loan repayment problems in case of moral hazard. Besides this, he further added that problems of multiple borrowing can be reduced through information sharing between lenders and borrowers. He also stated that the Credit Reference Bureau (CRB) can be established sector-wise to avoid the issue of over-indebtedness and the detrimental impact of multiple borrowing on loan repayment performance. (W. N. Green, 2020). Multiple borrowing created severe loan repayment problems if the firms and banks are subject to moral hazard and monitoring of client for utilization of loan amount is essential. They further added that multiple borrowing leads to over-indebtedness and over-indebtedness leads to loan repayment performance issues in the context of moral hazard and banks unable to overcome this issue due to lower equity and high monitoring cost (Afonso, Morvant-Roux, Guérin, \& Forcella, 2017).

The decision of taking a loan from more than one MFIs increases over-indebtedness as borrowers invested in various projects that reduce the probability that all investors would generate profit. If one of the investments did not provide sufficient return, then the return of a subsequent investment will be insufficient to meet the total repayment obligations of various outstanding loans. He further added that due to information asymmetry between borrowers and lenders, 
borrowers succeeded to obtain loans from more than one MFIs that increase their likelihood of over-indebtedness and ultimately affect the loan repayment performance (Casini, 2015). The core benefits of multiple borrowing are that borrowers can borrow from various formal and informal sources but this act of borrowers may lead to over-indebtedness, poor business performance, and then ultimately client fails to repay their outstanding loan (Guérin, Labie, \& MorvantRoux, 2018).

$\mathbf{H}_{4}$ : Over-Indebtedness has mediating impact between Multiple Borrowing and Loan Repayment Performance in the context of MFIs Clients.

\section{Moderating impact of moral hazard on the relationship of over-indebtedness and loan repayment performance}

In the existing studies, it is found that majority of MFIs borrowers who were found in multiple borrowing to be opportunity-driven and creating a diversion from loan purpose by spending loan amount to fulfill his/her basic needs (Spending loan amount on health \& medication, construction of a house, education expenses or on marriages of their family members) and to improve living standard (Spending loan amount for purchase of electric appliances, purchase of a motorcycle, important mobile phone and improving sanitation system). Therefore, these types of opportunity-driven client do not invest loan amount on income-generating activities and ultimately faces the over-indebtedness issue that creates severe loan repayment problems. (Mapogole et al, 2012; Faruqee and Khalily, 2011; Hidajat, 2021). On the other's hands distress-driven cross borrowing create moral hazard issue and MFIs borrower create a diversion from loan purpose due to unexpected events such as spending loan amount on health and medication, to pay educational expenses of a family member, construction of a house or to pay the existing loan principal amount or interest (Indarte, 2020; 2011; Burki, 2009; Faruqee and Khalily, 2011).

In terms of net revenue, net reserves, nutrition, and non-food expenditure multiple borrowers were better as compared to their peers. They further added that multiple borrowers used their net income for the repayment of loans. Hence, in this study, no adverse effect of multiple borrowing on loan repayment performance was found. Therefore, the crunch of discussions is that multiple borrowing was not a key issue that leads to loan repayment performance, the major problem is that how effectively and efficiently borrowers used the loan amount which also allowed them to gather savings to deal with crises (Faruqee and Khalily, 2011). In most cases, multiple borrowing adversely affects their financial basis, which has long terms impact on their business performance. For instance, multiple borrowers if default then they were not able to generate sufficient income from their business to fulfill their loan obligations. In consequence, they may be unable to fulfill their basic needs, and then they borrowers from a different lender to fulfill their basic needs and are caught in the trap of over-indebtedness (Indarte, 2020).

$\mathbf{H}_{5}$ : Moral Hazard has a moderating effect on the relationship of Over-Indebtedness and Loan Repayment Performance in the context of MFIs Clients in Pakistan.

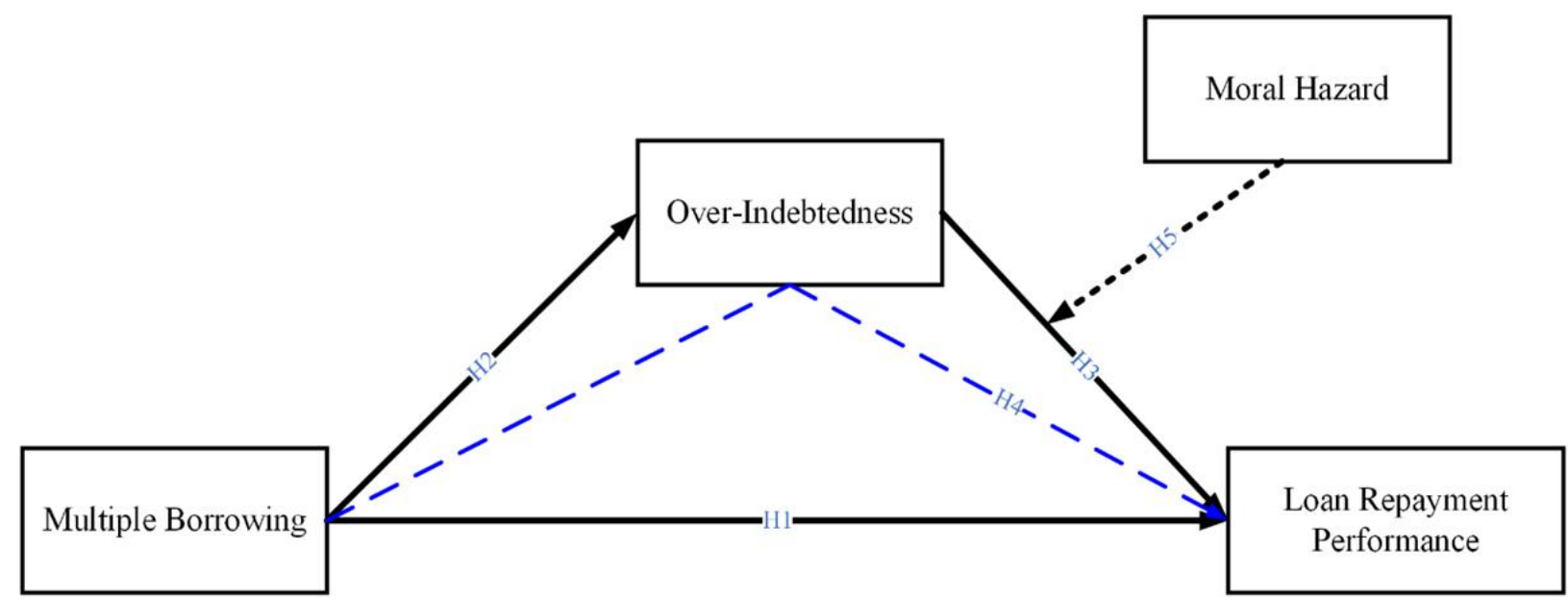

Figure 1: Hypothesized Conceptual Frame Work

\section{METHODOLOGY}

Based on the previous literature, premeditated directions are normally operationalized from the MFIs level perspective as MFIs employees have more knowledge on this topic, therefore MFIs employees have been taken as the target population in this study (Masocha \& Fatoki, 2018). Therefore, a unit of investigation of this study is the MFIs employees and mark respondents will be the Credit Officer/Lending Officer, Operations Managers, and Branch Manager. The target population will be the employees of MFIs Institution that will be divided into three different categories including Branch Manager, Operations Manager, and Lending Officer/Credit Officer/Loan Officer. The sample will be collected from each category randomly by applying the Stratified Sampling Technique (Mensah \& Ishmael, 2014). The sample size will 
be comprised of 531 employees of Microfinance Institutions (MFIs) and data collection tools will be structural questionnaires.

This research employed a quantitative approach, in which numbers were utilized to represent the phenomenon under investigation. The research model comprises four reflective constructs including Loan Repayment Performance (PRP), Moral Hazard (MHZ), Multiple Borrowing (MPB), and Over-Indebtedness (OID). In this study survey research design will be adopted and data will be collected from the target population through a questionnaire on a five-point Likert Scale ( $1=$ Strongly Disagree, $2=$ Disagree, $3=$ Neutral, $4=$ Agree, and $5=$ Strongly Agreed). The major technique for data collection was a questionnaire. A questionnaire is the most suited instrument since it can capture a big amount of data in a relatively short time and at a low cost. It protects the source of information's secrecy by ensuring anonymity while maintaining standards. Furthermore, because all of the respondents are well-educated and knowledgeable about the study's issue, a questionnaire was chosen as an appropriate tool for this study (Kwambai \& Wandera, 2013).

This study will comply with the Partial Least Square Model to analyze the collected data. Smart-PLS-SEM was used to observe the outer model that indicates the reliability and validity of the instrument through various tools including Factor Loading, Cronbach Alpha, Composite Reliability, Average Variance Extracted (AVE), Variance Inflation Factors (VIF), Fornell-Larcker Criterion, and HTMT Ratio. Moreover, the inner model will observe to found the significance of the path coefficients, coefficient determination, the effect size, and predictive relevance. (Aliman et al., 2017).

\section{DATA ANALYSIS AND RESULTS}

Table 1: Indicated the basic demographic and socio-economic features of the target respondent of the study.

Table 1: Demographic \& Socio-Economic Characteristics

\begin{tabular}{|c|c|c|c|c|}
\hline Variables & Category & Frequency & Percent & Cumulative Percent \\
\hline \multirow{4}{*}{ Gender } & Male & 460.00 & 86.63 & 86.63 \\
\hline & Female & 71.00 & 13.37 & 100.00 \\
\hline & Transgender & 0.00 & 0.00 & 100.00 \\
\hline & Total & 531.00 & 100.00 & \\
\hline \multirow{6}{*}{ Age } & $18-29$ & 120.00 & 22.60 & 22.60 \\
\hline & $30-39$ & 225.00 & 42.37 & 64.97 \\
\hline & $40-49$ & 101.00 & 19.02 & 83.99 \\
\hline & $50-59$ & 85.00 & 16.01 & 100.00 \\
\hline & 60-Above & 0.00 & 0.00 & 100.00 \\
\hline & Total & 531.00 & 100.00 & \\
\hline \multirow{3}{*}{ Marital Status } & Single & 325.00 & 61.21 & 61.21 \\
\hline & Married & 206.00 & 38.79 & 100.00 \\
\hline & Total & 531.00 & 100.00 & \\
\hline \multirow{6}{*}{ Qualification } & Metric & 51.00 & 9.60 & 9.60 \\
\hline & Intermediate & 80.00 & 15.07 & 24.67 \\
\hline & Graduation & 140.00 & 26.37 & 51.04 \\
\hline & Master & 220.00 & 41.43 & 92.47 \\
\hline & M.Phil. & 40.00 & 7.53 & 100.00 \\
\hline & TOTAL & 531.00 & 100.00 & \\
\hline \multirow{5}{*}{ Designation } & Credit Officer/Lending Officer & 305.00 & 57.44 & 57.44 \\
\hline & Operations Manager & 104.00 & 19.59 & 77.02 \\
\hline & Branch Manager & 72.00 & 13.56 & 90.58 \\
\hline & Regional Manager & 50.00 & 9.42 & 100.00 \\
\hline & Total & 531.00 & 100.00 & \\
\hline \multirow{5}{*}{$\begin{array}{l}\text { Banking Experience } \\
\text { (In Years) }\end{array}$} & $1-2$ & 170.00 & 32.02 & 32.02 \\
\hline & $3-4$ & 158.00 & 29.76 & 61.77 \\
\hline & $5-6$ & 108.00 & 20.34 & 82.11 \\
\hline & 7-Above & 95.00 & 17.89 & 100.00 \\
\hline & Total & 531.00 & 100.00 & \\
\hline
\end{tabular}

\section{Measurement Model}

PLS-SEM outer model is used to analyze the reliability and validity of the instrument used for data collection (Aliman et al., 2017). The inner model findings or impact of a different variable on each other's or relationship between observed variables of the study also depends upon the reliability and validity of the instrument. Hence, suitability of the outer model in terms of validity and reliability may be observed by looking at: (1) Factor Loading, (2) Cronbach's Alpha, (3) 
Composite Reliability (CR), (4) Average Variance Extracted (AVE), (5) Variance Inflation Factor (VIF), (6), FornellLarcker Criterion and (7) HTMT Ratio.

Table 2: Reliability and Validity

\begin{tabular}{|c|c|c|c|c|c|}
\hline Item Code & $\begin{array}{l}\text { Factor- } \\
\text { Loading }\end{array}$ & $\begin{array}{l}\text { Cronbach's } \\
\text { Alpha }\end{array}$ & $\begin{array}{l}\text { Composite- } \\
\text { Reliability }\end{array}$ & $\begin{array}{l}\text { Average- Variance- } \\
\text { Extracted- (AVE) }\end{array}$ & $\begin{array}{l}\text { Variance- Inflation- } \\
\text { Factor-(VIF). }\end{array}$ \\
\hline \multicolumn{6}{|c|}{ Loan-Repayment-Performance } \\
\hline LRP1 & 0.768 & \multirow{4}{*}{0.740} & \multirow{4}{*}{0.840} & \multirow{4}{*}{0.570} & 1.642 \\
\hline LRP2 & 0.807 & & & & 1.755 \\
\hline LRP3 & 0.784 & & & & 1.441 \\
\hline LRP4 & 0.635 & & & & 1.217 \\
\hline \multicolumn{6}{|c|}{ Moral-Hazard } \\
\hline MHZ1 & 0.616 & \multirow{5}{*}{0.870} & \multirow{5}{*}{0.910} & \multirow{5}{*}{0.670} & 1.273 \\
\hline MHZ2 & 0.873 & & & & 3.305 \\
\hline MHZ3 & 0.893 & & & & 3.527 \\
\hline MHZ4 & 0.871 & & & & 2.590 \\
\hline MHZ5 & 0.813 & & & & 2.312 \\
\hline \multicolumn{6}{|c|}{ Multiple Borrowing } \\
\hline MPB1 & 0.842 & \multirow{5}{*}{0.870} & \multirow{5}{*}{0.910} & \multirow{5}{*}{0.660} & 2.438 \\
\hline MPB2 & 0.823 & & & & 2.270 \\
\hline MPB3 & 0.762 & & & & 1.728 \\
\hline MPB4 & 0.807 & & & & 2.024 \\
\hline MPB5 & 0.829 & & & & 2.129 \\
\hline \multicolumn{6}{|c|}{ Over-Indebtedness } \\
\hline OID2 & 0.739 & \multirow{4}{*}{0.810} & \multirow{4}{*}{0.870} & \multirow{4}{*}{0.630} & 1.584 \\
\hline OID3 & 0.822 & & & & 1.957 \\
\hline OID4 & 0.774 & & & & 1.420 \\
\hline OID5 & 0.842 & & & & 1.987 \\
\hline
\end{tabular}

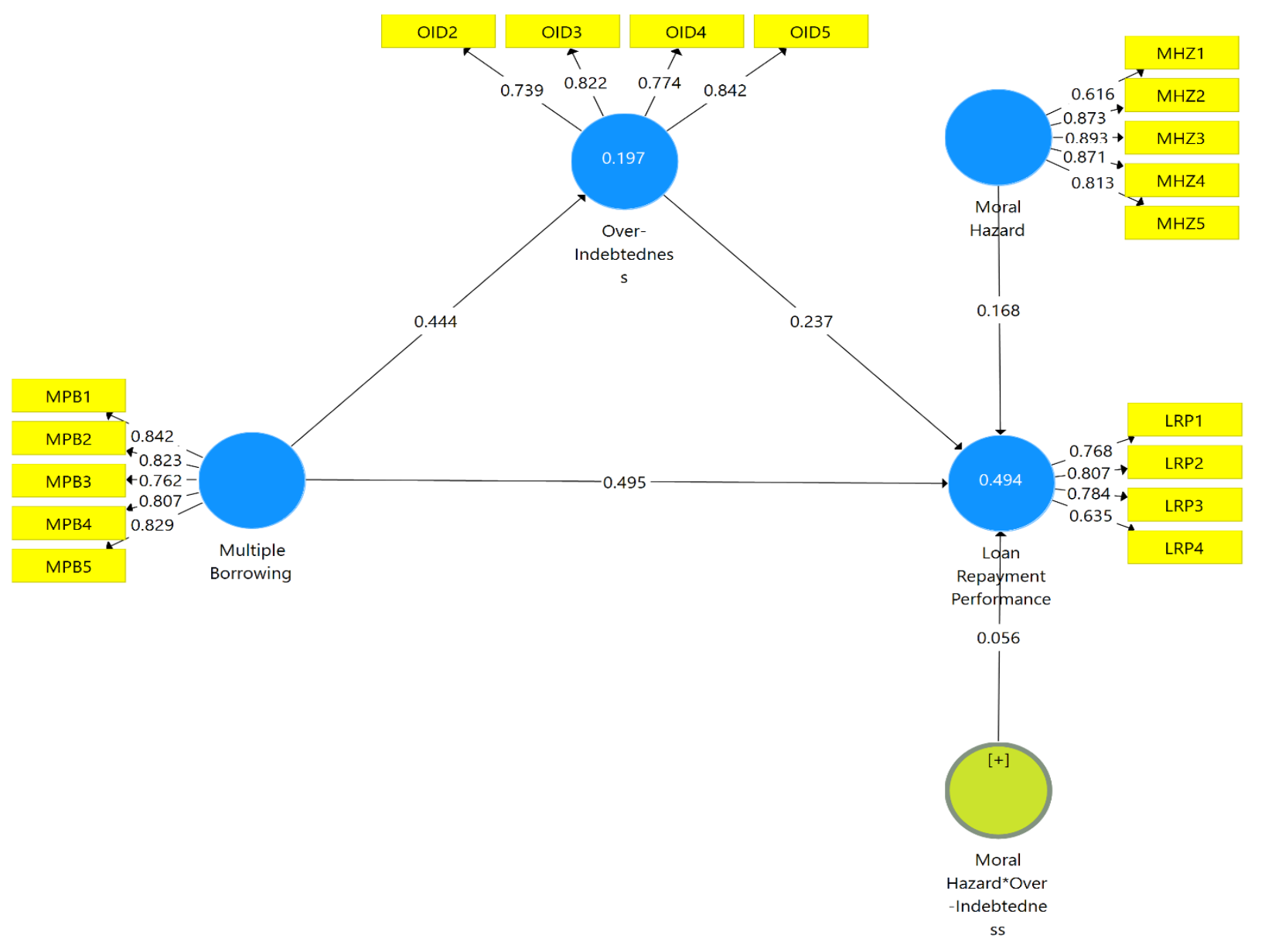

Figure 2: Measurement Model 
Factor loadings are used to ensure that items of the questionnaire serve the purpose that is envisioned to measure (Joe F Hair, Ringle, \& Sarstedt, 2011). The factor loading value of items greater than 0.60 is considered better (Hulland, 1999). Table 4.2 indicated the reliability and validity of the construct. Factor loading of each item is greater than 0.60 and acceptable in the light of the threshold suggested by Hulland. Moreover, Cronbach's alpha values of constructs were examining, and Table 4.2 showed that Composite reliability (CR) and Cronbach's alpha values greater than the threshold 0.70 (Hair Jr. et al., 2011). The value of Composite Reliability (CR) lies between the range of 0.840 to 0.910 that indicated that the measurement model is highly reliable and can be used for further analysis.

Average Variance Extracted (AVE) is used to establish the convergent validity of the construct. A value of 0.50 of AVE is a threshold to establish the convergent validity that is suggested by (Henseler et al., 2009). Table 4.2 indicates that the Average Variance Extracted (AVE) value of all the variables exceeding the recommended threshold of 0.50 is acceptable as the AVE value of all variables lies between the range of 0.570 to 0.670 . Variance Inflation Factor is another important measure used to measure the collinearity between the items of each construct. Value of VIF less than 3.3 is the threshold suggested by (Kock, 2015). According to Table 4.2, VIF values of each item of each construct are less than 3.30 that is an acceptable value, and indicated that no collinearity was found between the items of each construct.

Measurement of discriminant validity is complimentary for any research that includes latent variables and discriminant validity ensures that latent variables that are used in any research are not correlated with each other. Discriminant validity also ensured that two latent variables that belong to different theoretical measures are not the same statistically. The most prominent method applied to measure the discriminant validity is the Fornell-Larcker criterion ( $\underline{\mathrm{Ab} H a m i d}$, Sami, \& Sidek, 2017). The discriminant validity also ensured that all constructs used in any research are statistically different from each other's (Hair Jr. et al., 2011). In this study square root of Average-Variance-Extracted (AVE) of each construct has been compared with a correlation matrix to measure the discriminant validity. Table 4.3 indicates the Fornell-Larcker-Criterion assessment with the square root of the constructs. As per findings mentioned in Table 4.3, discriminant validity on the construct has been established as the AVE in bold is higher than its highest constructs correlation with any other constructs (Hair Jr. et al., 2011; Henseler et al., 2013).

Table 3: Fornell-Larcker Criterion (Discriminant-Validity)

\begin{tabular}{lllll}
\hline Constructs & $\mathbf{( 1 )}$ & $\mathbf{( 2 )}$ & $\mathbf{( 3 )}$ & $\mathbf{( 4 )}$ \\
\hline (1) Loan Repayment Performance & $\mathbf{0 . 7 5 2}$ & & & \\
\hline (2) Moral Hazard & 0.327 & $\mathbf{0 . 8 2 0}$ & & \\
\hline (3) Multiple Borrowing & 0.645 & 0.217 & $\mathbf{0 . 8 1 3}$ & \\
\hline (4) Over-Indebtedness & 0.473 & 0.151 & 0.444 & $\mathbf{0 . 7 9 5}$ \\
\hline
\end{tabular}

However, another important method introduced by Henseler and Sarstedt (2013) for establishing discriminant validity is the Heterotrain-Monotrait (HTMT) Ratio of correlation. HTML ratio is the replication of Monte Carlo and a threshold value less than 0.85 is considered acceptable. Table 4.4 indicated the values of the HTMT ratio and all values of the HTMT ratio below the 0.85 thresholds that ensured the discriminant validity of the construct.

Table 4: HTMT Ratio (Discriminant Validity)

\begin{tabular}{lllll}
\hline Constructs & (1) & (2) & (3) & (4) \\
\hline (1) Loan Repayment Performance & & & & \\
\hline (2) Moral Hazard & 0.411 & & \\
\hline (3) Multiple Borrowing & 0.796 & 0.247 & \\
\hline (4) Over-Indebtedness & 0.598 & 0.175 & 0.512 \\
\hline
\end{tabular}

\section{Structure Model}

As per the measurement model (outer model), reliability and validity have been established in the light of different techniques including (1) Factor Loading (2) Cronbach's Alpha (3) Composite Reliability (4) Average Variance Extracted (5) Variance Inflation Factor (6) Fornell-Larcker Criterion and (7) HTMT Ratio. After establishing the validity and reliability, the next step involves accessing the findings of the structural model (Inner Model). According to Hair Jr. et al. (2013) the prime criteria for observing the structural model in PLS-SEM are the significance of the path coefficients, $t$-value, and coefficient determination- $\left(\mathrm{R}^{2}\right)$. Whereas intervention investigation measures the ancillary effect of an autonomous variable on the dependent variable through the mediating variable. Various ways for mediating analysis were proposed by various academics, however bootstrapping methods have a considerable benefit since bootstrapping generates an empirical representation of the indirect impact sample distribution (Rucker, Preacher, Tormala, \& Petty, 2011). Various researches have suggested the justification and benefits of bootstrapping in the context of direct relation and mediating analysis. The prime feature of bootstrapping approach is that it does not require any assumption regarding sample distributions of the indirect impact or its product. (Hair Jr. et al., 2013; Hayes \& Preacher, 2010).

Hence, this study tested the impact of multiple borrowing on loan repayment performance through the mediation of over-indebtedness and by incorporating the moderating impact of moral hazard by using Smart-PLS-SEM with a sample 
size of 532. Therefore, it is detected from Table 4.5 that $\left(\mathrm{H}_{1}\right)$ multiple borrowing has a direct impact on loan repayment performance is accepted $(\beta .0 .496 ; \mathrm{t}=11.91 ; \mathrm{p}<.000)$. Whereas $\left(\mathrm{H}_{2}\right)$ multiple borrowing has a direct impact on overindebtedness accepted $(\beta$. $0.444 ; \mathrm{t}=12.25 ; \mathrm{p}<.000)$. Moreover, $\left(\mathrm{H}_{3}\right)$ direct impact of over-indebtedness on loan repayment performance is also accepted because $(\beta .0 .237 ; \mathrm{t}=06.17 ; \mathrm{p}<.000)$. After that $\left(\mathrm{H}_{4}\right)$ over-indebtedness has a mediating role between moral hazard and loan repayment accepted as $(\beta .0 .105 ; \mathrm{t}=5.461 ; \mathrm{p}<.000)$. However, moral hazard moderate the relationship of over-indebtedness and loan repayment performance also accepted at a $10 \%$ significance level $(\beta .0 .056 ; \mathrm{t}=1.83 ; \mathrm{p}<.065)$.

Table 5: Hypothesis-Testing

\begin{tabular}{llll}
\hline Hypothesis & $\begin{array}{l}\text { Path- } \\
\text { Coefficient }\end{array}$ & $\begin{array}{l}\text { T- } \\
\text { stats }\end{array}$ & $\begin{array}{l}\text { P- } \\
\text { Values }\end{array}$ \\
\hline H1: Multiple Borrowing -> Loan Repayment Performance & 0.496 & 11.91 & $0.000^{* * *}$ \\
\hline H2: Multiple Borrowing -> Over-Indebtedness & 0.444 & 12.25 & $0.000 * * *$ \\
\hline H3: Over-Indebtedness -> Loan Repayment Performance & 0.237 & 6.17 & $0.000^{* * *}$ \\
\hline $\begin{array}{l}\text { H4: Multiple Borrowing -> Over-Indebtedness -> Loan Repayment } \\
\text { Performance }\end{array}$ & 0.105 & 5.461 & $0.000^{* * *}$ \\
\hline H5: Moral Hazard*Over-Indebtedness -> Loan Repayment Performance & 0.056 & 1.83 & $0.065^{*}$ \\
\hline
\end{tabular}

Note: $* * *, * *, *$ indicates level of significance at $1 \%, 5 \%, 10 \%$ respectively.

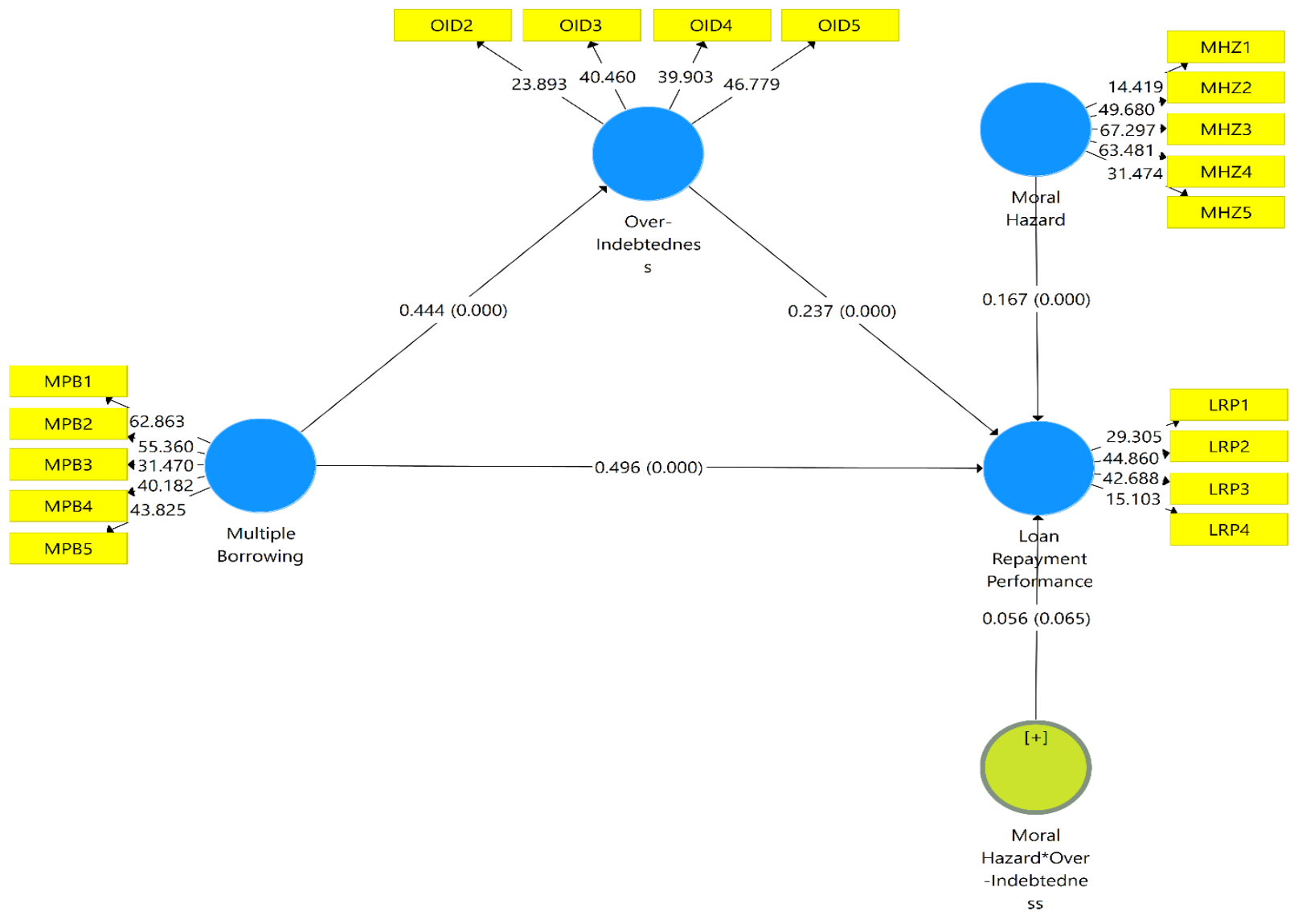

Figure 3: Structural Model

Table 6: Hypothesis-Testing Results Summary

\begin{tabular}{lllll}
\hline Hypothesis & $\begin{array}{l}\text { Path- } \\
\text { Coefficient }\end{array}$ & T-stats & P-Values & Decision \\
\hline H1: Multiple Borrowing -> Loan Repayment Performance & 0.496 & 11.91 & $0.000^{* * *}$ & Accepted \\
\hline H2: Multiple Borrowing -> Over-Indebtedness & 0.444 & 12.25 & $0.000^{* * *}$ & Accepted \\
\hline H3: Over-Indebtedness -> Loan Repayment Performance & 0.237 & 6.17 & $0.000^{* * *}$ & Accepted \\
\hline $\begin{array}{l}\text { H4: Multiple Borrowing -> Over-Indebtedness -> Loan } \\
\text { Repayment Performance }\end{array}$ & 0.105 & 5.461 & $0.000^{* * *}$ & Accepted \\
\hline $\begin{array}{l}\text { H5: Moral Hazard*Over-Indebtedness -> Loan Repayment } \\
\text { Performance }\end{array}$ & 0.056 & 1.83 & $0.065^{*}$ & Accepted \\
\hline
\end{tabular}




\section{DISCUSSION}

The predetermined objectives for this research are to determine the impact of multiple borrowing on loan repayment performance by keeping in view the mediating impact of over-indebtedness and moderating the role of moral hazard. So, five hypotheses having both direct and indirect impact were proposed and tested by using the bootstrapping methods in PLS-SEM. To obtain the predetermined objectives, $\left(\mathbf{H}_{\mathbf{1}}\right)$ Multiple Borrowing has a direct impact on Loan Repayment Performance in the context of MFIs Client in Pakistan was tested and the hypothesis was accepted based on the results mentioned in Table 4.5. The findings of $\mathrm{H}_{1}$ indicates that those borrowers who obtain loan from different lenders facing problems when loans reached to its maturity level. These findings are also consistent with (Puliyakot, 2020; Mwashiuya \& Mbamba, 2020; Dhungana, Chapagain, and Ranabhat, 2020; Chaudhury and Matin, 2002; Dattasharma, Kamath, and Ramanathan, 2016; Aliman et al., 2017).

Secondly, $\left(\mathbf{H}_{\mathbf{2}}\right)$ Multiple Borrowing has a direct impact on Over-Indebtedness in the context of MFIs Clients in Pakistan was tested and accepted based on findings mentioned in Table 4.5. Findings of this hypothesis indicated that those clients who obtain credit facility from more than one lenders found enhancement in their indebtedness level and ultimately found himself/themselves in a debt trap permanently. Findings of this hypothesis are also supported by various studies including (Chichaibelu \& Waibel, 2017; Schicks, 2014; Shreya, 2021; Maurer, and Pytkowska, 2011). Thirdly, Over-Indebtedness has a direct impact on Loan Repayment Performance in the context of MFIs Client in Pakistan $\left(\mathbf{H}_{3}\right)$ is also tested and accepted based on bootstrapping results mentioned in Table 4.5. This finding indicates that over-indebted client consistently remains in a debt trap and fails to fulfill his/her debt obligation as per contractual agreement and unable to pay their outstanding loans at the time of maturity. This finding also in line with different studies including (Lamichhane, 2021; Burki, 2009; Faruqee, Khalily, Akhter, and Alam, 2011).

Fourthly, Over-Indebtedness has mediating impact between Multiple Borrowing and Loan Repayment Performance in the context of MFIs Clients $\left(\mathbf{H}_{4}\right)$ also accepted based on bootstrapping results mentioned in Table 4.5. The findings of this hypothesis indicated that those MFIs client who obtain credit facilities from more than one lender enhance their indebtedness level and due to over-indebtedness level facing serious loan repayment problems and unable to fulfill his/her loan contractual obligation as per lending agreement. The results of this hypothesis also consistent with (W. N. Green, 2020; Afonso, Morvant-Roux, Guérin, \& Forcella, 2017; Casini, 2015; Guérin, Labie, \& Morvant-Roux, 2018). Lastly, $\left(\mathbf{H}_{5}\right)$ Moral Hazard have moderating effect on the relationship of Over-Indebtedness and Loan Repayment Performance in the context of MFIs Clients in Pakistan was also tested and accepted as per criteria mentioned in Table 4.5. As per findings related to this hypothesis over-indebted client seeks credit and used loan amount on social disbursement (Health, education, construction, marriages, etc) instead of investing in a business or income-generating activities. As earlier mentioned over-indebted clients also facing loan repayment problems. Therefore, moral hazard strong the relationship of over-indebtedness and loan repayment performance. In short, we can say that that client found in moral hazard enhance their indebtedness level and facing more problems in loan repayment. The findings of this hypothesis are also consistent with (Mpogole et al, 2012; Faruqee and Khalily, 2011; Hidajat, 2021; Indarte, 2020; Burki, 2009).

\section{CONCLUSION}

Finally, I conclude that multiple borrowing in the context of Pakistan with special reference to MFIs is a bad sign, and the majority of MFIs clients who found in multiple borrowing enhancing their indebtedness level due to moral hazard and finally unable to pay its outstanding debts at the time of maturity.

\section{LIMITATION OF THE STUDY}

The researcher has to face a large number of constraints for researching social sciences as the majority of study in social sciences conducted in a controlled manner. Besides this, researcher of underdeveloped societies like Pakistan has to face some additional challenges due to underdeveloped nature of society, lower literacy rate and poor quality of education. Therefore, people foot-dragging to provide data and not cooperate with the researcher at all in the context of sparing time for fulfillment of questionnaire and interview. Besides all this, many factors affecting the Loan Repayment Performance of MFIs such as outreach, personal characteristics of the borrower, policy support, and using innovative features.

\section{POLICY IMPLICATION AND FUTURE DIRECTION}

Later on, findings of this study will be shared with all stakeholders including all Microfinance Institutions (MFIs), NGOs, Government, and client/borrower so that loan repayment performance, Performance of MFIs, and performance of client/borrowers may be enhanced and policies may be formulated to overcomes on these factors that adversely affect the loan repayment performance of MFIs clients. Although this study makes an impactful contribution to the field of multiple borrowing and loan repayment performances further investigation will be needed. First, the scope of this study can be extended to informal MFIs. Secondly, Multiple borrowing may be divided into further categories including progress lending and repeated client, and the impact of these categories can also be incorporated. Lastly, other 
uncontrollable factors like pandemic factors (Covid-19, floods, livestock diseases) can also be taken as moderating variables.

\section{AUTHOR CONTRIBUTIONS}

Zahid Iqbal: Model building, idea generation, data collection, abstract and conclusion writing, review of articles, and correspondence with the journal.

Dr. Muhammad Akram: Write literature review and proofreading of the whole paper.

Dr. Hassaan Ahmad: Write methodology section and data analysis.

\section{REFERENCES}

1. Ab Hamid , M. R., Sami, W., \& Sidek, M. H. M. (2017). Discriminant validity assessment: Use of Fornell \& Larcker criterion versus HTMT criterion, 890, 012163. https://doi.org/10.1088/1742-6596/890/1/012163

2. Afonso, J. S., Morvant-Roux, S., Guérin, I., \& Forcella, D. (2017). Doing Good by Doing Well? Microfinance, Self-Regulation and Borrowers' Over-indebtedness in the Dominican Republic. Journal of International Development, 29(7), 919-935. https://doi.org/10.1002/jid.3244

3. Aliman, N., Ramli, R., \& Haris, S. M. (2017). Design and development of lower limb exoskeletons: A survey. Robotics and Autonomous Systems, 95, 102-116. https://doi.org/10.1016/j.robot.2017.05.013

4. Bond, P., \& Rai, A. S. (2009). Borrower runs. Journal of development Economics, 88(2), $185-191$. https://doi.org/10.1016/j.jdeveco.2008.06.005

5. Burki, H.-B. (2009). Unraveling the Delinquency Problem (2008/2009) in Punjab, Pakistan. Pakistan Microfinance Network, MicroNote, 10, 1-34.

6. Casini, P. (2015). Competitive microcredit markets: differentiation and ex ante incentives for multiple borrowing. Oxford Economic Papers, 67(4), 1015-1033. https://doi.org/10.1093/oep/gpv047

7. Chaudhury, I. A., \& Matin, I. (2002). Dimensions and dynamics of microfinance membership overlap-a micro study from Bangladesh. Small Enterprise Development, 13(2), 46-55. https://doi.org/10.3362/09571329.2002.021

8. Chen, J., Chang, A. Y., \& Bruton, G. D. (2017). Microfinance: Where are we today and where should the research go in the future? International Small Business Journal, 35(7), 793-802. https://doi.org/10.11 $7 / 0266242617717380$

9. Chichaibelu, B. B., \& Waibel, H. (2017). Borrowing from "pui" to pay "pom": Multiple borrowing and overindebtedness in rural Thailand. World development, 98, 338-350. https://doi.org/10.1016/j.world dev.2017.04.032

10. Dattasharma, A., Kamath, R., \& Ramanathan, S. (2016). The burden of microfinance debt: Lessons from the ramanagaram financial diaries. Development and Change, 47(1), 130-156. https://doi.org/10.1111/dech.12218

11. Debnath, K., \& Roy, P. (2018). Predicting multiple-borrowing default among microfinance clients. Theoretical Economics Letters, 8(10), 1772. https://doi.org/10.4236/tel.2018.810116

12. Dhungana, B. R., Chapagain, R., \& Ranabhat, D. (2020). Effects of Microfinance Intervention on Multiple and Non-multiple Financing Clients: A Case of Gandaki Province of Nepal. Journal of Nepalese Business Studies, 13(1), 49-61. https://doi.org/10.3126/jnbs.v13i1.34703

13. Diaz-Serrano, L., \& Sackey, F. G. (2018). Microfinance and credit rationing: does the microfinance type matter? Journal of Sustainable Finance \& Investment, 8(2), 114-131. https://doi.org/10.1080/204307 95.2017.1403181

14. Faruqee, R., Khalily, M. A. B., Akhter, N., \& Alam, M. (2011). Multiple borrowing by mfi clients. Policy Paper, Institute of Microfinance, Dhaka, Bangladesh.

15. Godquin, M. (2004). Microfinance repayment performance in Bangladesh: How to improve the allocation of loans by MFIs. World development, 32(11), 1909-1926. https://doi.org/10.1016/j.worlddev.2004.05.011

16. Green, D., \& Liu, E. (2021). A dynamic theory of multiple borrowing. Journal of Financial Economics, 139(2), 389-404. https://doi.org/10.1016/j.jfineco.2020.08.016

17. Green, W. N. (2020). Regulating Over-indebtedness: Local State Power in Cambodia's Microfinance Market. Development and Change, 51(6), 1429-1453. https://doi.org/10.1111/dech.12620

18. Guérin, I., Labie, M., \& Morvant-Roux, S. (2018). Inadequate growth, over-indebtedness, and crises in microcredit: What have we learned. Enterprise Development \& Microfinance, 29(2), 118-132. https://doi.org/10.3362/1755-1986.17-00013

19. Hair, J. F., Ringle, C. M., \& Sarstedt, M. (2011). PLS-SEM: Indeed a silver bullet. Journal of Marketing theory and Practice, 19(2), 139-152. https://doi.org/10.2753/MTP1069-6679190202

20. Hayes, A. F., \& Preacher, K. J. (2010). Quantifying and testing indirect effects in simple mediation models when the constituent paths are nonlinear. Multivariate behavioral research, 45(4), 627-660. https://doi.or $\mathrm{g} / 10.1080 / 00273171.2010 .498290$

21. Henseler, J., \& Sarstedt, M. (2013). Goodness-of-fit indices for partial least squares path modeling. Computational statistics, 28(2), 565-580. https://doi.org/10.1007/s00180-012-0317-1 
22. Hidajat, T. (2021). The Relationship Between Debt Literacy and Peer-To-Peer Lending: A Case Study in Indonesia. The Journal of Asian Finance, Economics and Business, 8(5), 403-411.

23. Hossain, S., Galbreath, J., Hasan, M. M., \& Randøy, T. (2020). Does competition enhance the double-bottomline performance of microfinance institutions? Journal of Banking \& Finance, 113, 105765. https://doi.org/10.1016/i.jbankfin.2020.105765

24. Hulland, J. (1999). Use of partial least squares (PLS) in strategic management research: a review of four recent studies. Strategic Management Journal, 20(2), 195-204. https://doi.org/10.1002/(SICI)10970266(199902)20:2<195::AID-SMJ13>3.0.CO;2-7

25. Indarte, S. (2020). Moral Hazard versus Liquidity in Household Bankruptcy.

26. Kock, N. (2015). Common method bias in PLS-SEM: A full collinearity assessment approach. International Journal of e-Collaboration (ijec), 11(4), 1-10. https://doi.org/10.4018/ijec.2015100101

27. Kwambai, K. D., \& Wandera, M. (2013). Effects of credit information sharing on nonperforming loans: the case of Kenya commercial bank Kenya. European Scientific Journal, 9(13). http://hdl.handle.net/123456789/75

28. Lamichhane, B. D. (2021). Client Satisfaction: Key Factors to Sustainability of Microfinance Institutions (MFIs). Interdisciplinary Journal of Management and Social Sciences, 2(1), 32-42. https://doi.org/10 .3126/ijmss.v2i1.36739

29. Masocha, R., \& Fatoki, O. (2018). The role of mimicry isomorphism in sustainable development operationalisation by SMEs in South Africa. Sustainability, 10(4), 1264. https://doi.org/10.3390/su10041264

30. Matzanke, M. (2014). Cross-borrowing and its impact on microentrepreneurs' repayment performance and well-being in Peru. http://gala.gre.ac.uk/id/eprint/11951

31. Maurer, K., \& Pytkowska, J. (2011). Indebtedness of Microfinance Clients in Bosnia and Herzegovina. Results from a Comprehensive Field Study. European Fund for Southeast Europe (EFSE) Development Facility, mimeo.

32. Mensah, I. (2014). Different shades of green: Environmental management in hotels in Accra. International Journal of Tourism Research, 16(5), 450-461. https://doi.org/10.1002/jtr.1939

33. Mpogole, H., Mwaungulu, I., Mlasu, S., \& Lubawa, G. (2012). Multiple borrowing and loan repayment: A study of microfinance clients at Iringa, Tanzania. Global Journal of Management and Business Research, 12(4), 97-102. http://creativecommons.org/licenses/by-nc/3.0/.

34. Muindi, C. W., \& Mutwiri, N. M. (2021). Collateral requirement as a determinant of portfolio quality of microfinance institutions: Why does it matter? Insights from microfinance banks in Kenya. International Academic Journal of Economics and Finance, 3(6), 362-374. http://iajournals.org/articles/iaje f_v3_i6_362_374.pdf

35. Mwashiuya, H. T., \& Mbamba, U. O. L. (2020). Relationship of information and communication technology adoption on microfinance institutions operational performance and access to financial services in Tanzania. International Journal of Information, Business and Management, 12(1), 214-237.

36. Orichom, G., \& Omeke, M. (2021). Capital structure, credit risk management and financial performance of microfinance institutions in Uganda. Journal of Economics and International Finance, 13(1), 24-31. https://doi.org/10.5897/JEIF2020.1096

37. Parvin, M. T., Birner, R., \& Mila, F. A. (2020). Factors Determining the Loan Repayment Performance of a Government Microcredit Program for the Handloom Weavers in Bangladesh. International Journal of Business \& Management Science, $10(1)$.

38. Puliyakot, S. (2020). Does Microfinance Participation Lead to Over-Indebtedness? Evidence from India. IUP Journal of Accounting Research \& Audit Practices, 19(3), 22-48.

39. Pytkowska, J., \& Spannuth, S. (2012). Indebtedness of microcredit clients in Kosovo: Results from a comprehensive field study. Microfinance Centre, Finance in Motion. t: https://www.researchgate .net/publication/298403888

40. Rucker, D. D., Preacher, K. J., Tormala, Z. L., \& Petty, R. E. (2011). Mediation analysis in social psychology: Current practices and new recommendations. Social and Personality Psychology Compass, 5(6), 359-371. https://doi.org/10.1111/j.1751-9004.2011.00355.x

41. Sangwan, S., Nayak, N. C., \& Samanta, D. (2020). Loan repayment behavior among the clients of Indian microfinance institutions: A household-level investigation. Journal of Human Behavior in the Social Environment, 30(4), 474-497. https://doi.org/10.1080/10911359.2019.1699221

42. Sawada, Y., Tanaka, M., \& Mahmud, M. (2018). Is multiple borrowing a bad sign? Evidence from Bangladesh and India. In Economic and Social Development of Bangladesh (pp. 199-214): Springer. https://doi.org/10.1 007/978-3-319-63838-6_10

43. Schicks, J. (2013). The sacrifices of micro-borrowers in Ghana-a customer-protection perspective on measuring over-indebtedness. The Journal of Development Studies, 49(9), 1238-1255. https://doi.org/10.1080/0 $\underline{0220388.2013 .775421}$

44. Schicks, J. (2014). Over-indebtedness in microfinance-an empirical analysis of related factors on the borrower level. World development, 54, 301-324. https://doi.org/10.1016/j.worlddev.2013.08.009 
45. Shreya, N. F. (2021). Are Two Sources of Credit better than One?: Credit Access and Debt among Microfinance Clients in Bangladesh.

46. State Bank of Pakistan. Financial Statement Analysis of Financial Sector (2015-19).

47. Vogelgesang, U. (2003). Microfinance in times of crisis: The effects of competition, rising indebtedness, and economic crisis on repayment behavior. World development, 31(12), 2085-2114. https://doi.org/10.1016/j. worlddev.2003.09.004 